\title{
PENGARUH MANAJEMEN LABA DAN KONSERVATISME AKUNTANSI TERHADAP NILAI PERUSAHAAN DENGAN KINERJA PERUSAHAAN SEBAGAI VARIABEL PEMODERASI
}

\section{THE EFFECT OF EARNINGS MANAGEMENT AND ACCOUNTING CONSERVATISM ON COMPANY VALUE WITH COMPANY PERFORMANCE AS A MODERATING VARIABLE}

\author{
Tumpal Manik \\ Universitas Maritim Raja Ali Haji - Tanjungpinang \\ tmanyk@gmail.com dan tmanik@umrah.ac.id
}

\begin{abstract}
ABSTRAK
Penelitian ini bertujuan untuk memberikan bukti empiris pengaruh manajemen laba dan konservatisme akuntansi terhadap nilai perusahaan dengan kinerja perusahaan sebagai variabel pemoderasi. Populasi penelitian pada perusahaan manufaktur yang terdaftar di Bursa Efek Indonesia tahun 2016 - 2017. Pengambilan sampel dilakukan dengan metode purposive sampling. Jumlah populasi 168 yang memenuhi kriteria sebanyak 40 perusahaan, maka data penelitian $40 \times 2$ tahun yaitu 80 data. Pengolahan data penelitian untuk menguji hipotesis penelitian secara simultan dan parsial. Hasil penelitian menunjukkan bahwa manajemen laba berpengaruh signifikan terhadap nilai perusahaan $-17,6 \%$, konservatisme berpengaruh signifikan terhadap nilai perusahaan $21,3 \%$, kinerja perusahaan berpengaruh sinifikan terhadap nilai perusahaan $22,7 \%$, manajemen berpengaruh sinifikan laba terhadap nilai perusahaan dengan kinerja perusahaan sebagai variabel pemoderasi $9 \%$. dan konservatisme berpengaruh sinifikan terhadap nilai perusahaan dengan kinerja perusahaan sebagai variabel pemoderasi $9 \%$
\end{abstract}

Kata kunci : Manajemen Laba, Konservatisme, Nilai Perusahaan dan Kinerja Perusahaan

\begin{abstract}
This reseach aims is to provide empirical evidence of the effect of earnings management and accounting conservatism on company value with company performance as a moderating variable. The population of research in manufacturing companies listed on the Indonesia Stock Exchange in 2016 - 2017. Sampling was done by purposive sampling method. The population of 168 fulfills the criteria of 40 companies, so the $40 \times 2$ year research data is 80 data. Research data processing to test the research hypothesis simultaneously and partially. The results showed that earnings management had a significant effect on firm value $-17.6 \%$, conservatism had a significant effect on company value $21.3 \%$, company performance had a significant effect on firm value $22.7 \%$, management had a significant effect on earnings and firm performance. as a moderating variable of $9 \%$. and conservatism has a significant effect on firm value with company performance as a moderating variable of $9 \%$
\end{abstract}

Keywords : Earning Management, Conservatism, Company Value and Company Performance

Hal. 1 


\section{PENDAHULUAN}

Pasar modal memfasilitasi berbagai sarana dan prasarana kegiatan jual beli dan kegiatan terkait bisnis lainnya karena pasar modal memiliki peran penting bagi perekonomian suatu negara menjalankan dua fungsi, yaitu pertama sebagai sarana bagi pendanaan usaha atau sebagai sarana bagi perusahaan untuk mendapatkan dana dari masyarakat pemodal (investor). Dana yang diperoleh dari pasar modal dapat digunakan untuk pengembangan usaha, ekspansi, penambahan modal kerja dan lain-lain, kedua pasar modal menjadi sarana bagi masyarakat untuk berinvestasi pada instrument keuangan seperti saham, obligasi, reksa dana.

Penerpan manajemen laba tidak selamanya bermakna negatif, terkadang manajemen melakukan untuk menyelamatkan kondisi perusahaan, Manajemen laba yang dimaksud dalam penelitian ini adalah tindakan manajemen yang dilakukan dengan tujuan untuk meningkatkan kemakmuran individu atau untuk meningkatkan nilai perusahaan. Akhir-akhir ini beberapa penelitian tentang manajemen laba yang memiliki pola dan konsep yang berbeda-beda untuk mencapai tujuan penelitian, sehingga para peneliti memiliki sasaran yang berbeda juga, maka istilah manajemen laba muncul sebagai konsekuensi langsung dari upaya-upaya manajer atau pembuat laporan keuangan untuk melakukan manajemen informasi akuntansi, khususnya laba, demi kepentingan pribadi dan perusahaan.

Beberapa penelitian yang menyatakan manajemen laba sama dengan konservatisme, namun dalam penelitian ini penulis mencaba menguraikan adanya perbedaan, yakni dalam prinsip konservatisme juga seringkali dikaitkan dengan kualitas laba dan nilai perusahaan, konservatisme akuntansi akan mempengaruhi baik kualitas laba yang dilaporkan dalam laporan keuangan perusahaan, sedangkan manajemen laba. berkaitan dengan praktik pemilihan metode akuntansi dilakukan oleh manajemen sebagai perilaku manager yang mempunyai weweang dalam penyusunan laporan keuangan melalui penerapan komponen discretionary accruals untuk menyusun penentuan besarnya laba, tanpa mengakibatkan dampak peningkatan maupun penurunan profitabilitas ekonomis jangka panjang perusahaan.

Konservatisme juga berhubungan dengan kinerja perusahaan dan nilai perusahaan misalnya jika terdapat sesuatu yang dapat meningkatkan aktiva, tetapi belum terealisasi, maka kejadian itu belum boleh diakui. Tetapi jika terdapat sesuatu yang mengakibatkan penurunan aktiva, walaupun belum terealisasi, maka kejadian itu harus sudah diakui. Dalam sebuah perusahaan memperbarui estimasi mengenai arus kas masa depan dari biaya pengembangan yang dikapitalisasinya, mungkin ada efek sementara konservatisme yang mengarah pada penciptaan cadangan tersembunyi yang kemudian dapat dibalik kembali (Reversed). Penyajian informasi keuangan dihadapkan pada prinsip kehati-hatian, yakni terhadap pencatatan pendapatan dan biaya, maupun pencatatan terhadap aktiva. Berdasarkan penjelasan diatas, maka penulis tertarik untuk menganalisis yang berjudul "Pengaruh Manajemen Laba Dan Konservatisme Akuntansi terhadap Nilai Perusahaan Dengan Kinerja Perusahaan Sebagai Variabel Pemoderasi"

Berdasarkan uraian latar belakang diatas, maka tujuan penelitian ini adalah untuk menganilisis secara empiris : 1) Pengaruh Manajemen laba terhadap nilai perusahaan, 2) Pengaruh Konservatisme terhadap nilai perusahaan, 3) Pengaruh Kinerja Perusahaan terhadap nilai perusahaan, 4) Pengaruh Manajemen laba terhadap nilai perusahaan dengan Kinerja Perusahaan sebagai variabel pemoderasi, 5) Pengaruh Konservatisme terhadap nilai perusahaan dengan Kinerja Perusahaan sebagai variabel pemoderasi. 


\section{LANDASAN TEORI}

\section{Manajemen Laba (Earnings Management)}

Manajemen laba tidak dapat diartikan sebagai suatu upaya negatif yang merugikan karena, tidak selamanya manajemen laba berorientasi pada manipulasi laba. Manajemen laba menjadi menarik untuk diteliti karena dapat memberikan gambaran akan perilaku manajer dalam melaporkan kegiatan-kegiatan usaha, Manajemen laba yang dimaksud dalam penelitian ini adalah tindakan manajemen yang dilakukan dengan tujuan untuk meningkatkan kemakmuran individu atau untuk meningkatkan nilai perusahaan. Akhir-akhir ini beberapa penelitian tentang manajemen laba yang memiliki pola dan konsep yang berbeda-beda untuk mencapai tujuan penelitian, sehingga para peneliti memiliki sasaran yang berbeda juga, maka istilah manajemen laba muncul sebagai konsekuensi langsung dari upaya-upaya manajer atau pembuat laporan keuangan untuk melakukan manajemen informasi akuntansi, khususnya laba, demi kepentingan pribadi dan perusahaan.

Praktik manajemen laba dikaji berdasarkan data informasi laporan keuangan, manajer dapat menggunakan praktik manajemen laba untuk menentukan analisa laba perusahaaan. Jika pada suatu kondisi, dimana pihak manajemen ternyata tidak berhasil mencapai target laba yang ditentukan. Jika perusahaan akan menjual sahamnya kepada publik, manajer perlu memberikan informasi kepada publik mengenai kondisi keuangan perusahaannya, hal ini mendorong manajer untuk melakukan earnings management. Dalam konteks penelitian ini, istilah manajemen laba didefinisikan sebagai upaya-upaya manajemen untuk menyusun laporan keuangan sehingga dapat menyesatkan para pengambil keputusan dalam menilai kinerja (Manik, 2010).

Istilah manajemen laba berkaitan dengan praktik pemilihan metode akuntansi dilakukan oleh manajemen sebagai perilaku manager yang mempunyai weweang dalam penyusunan laporan keuangan melalui penerapan komponen discretionary accruals untuk menyusun penentuan besarnya laba, kemudian perlakukan manajer tersebut memiliki wewenang untuk meningkatkan ataupun mengurangi laba yang dilaporkan saat ini tanpa mengakibatkan dampak peningkatan maupun penurunan profitabilitas ekonomis jangka panjang perusahaan.

Menurut Scott (2003), teknik pengaturan laba atau praktik manajemen laba terdiri dari lima bentuk yaitu; 1) Taking a bath; terjadi selama periode dimana terjadi tekanan dalam organisasi atau terjadi reorganisasi, misalnya penggantian direksi. Jika teknik ini digunakan maka biayabiaya yang ada pada periode yang akan datang diakui pada periode berjalan. Ini dilakukan jika kondisi yang tidak menguntungkan tidak bisa dihindari. Akibatnya, laba pada periode yang akan datang menjadi tinggi meskipun kondisi tidak menguntungkan. 2).Income minimization; pola meminimumkan laba mungkin dilakukan karena motif politik atau motif meminimunkan pajak. Cara ini dilakukan pada saat perusahaan memperoleh profitabilitas yang tinggi dengan tujuan agar tidak mendapat perhatian secara politis. Kebijakan yang diambil dapat berupa penghapusan (write off) atas barang-barang modal dan aktiva tak berwujud, pembebanan pengeluaran. 3) Income maximization; maksimalkan laba bertujuan untuk memperoleh bonus yang lebih besar, selain itu tindakan ini juga bisadilakukan untuk menghindari pelanggaran atas kontrak hutang jangka panjang (debt covenant). 4) Income smoothing; yakni memilih untuk melaporkan trend pertumbuhan laba yang stabil dari pada menunjukkan perubahan laba yang meningkat atau menurun secara drastis. 5).Timing Revenue dan Expenses Recognation; teknik yang dilakukan dengan membuat kebijakan tertentu yang berkaitan dengan timing suatu transaksi, misalnya pengakuan premature atas pendapatan. 
Menurut Sulistiyono (2008), Laba yang dilaporkan melalui menajemen laba acrual merupakan selisih antara kas masuk bersih dari hasil operasi perusahaan dengan laba yang dilaporkan dalam laporan laba-rugi, yang bisa bersifat akrual diskresioner dan akrual nondiskresioner. Akrual diskresioner terdiri dari akrual diskresioner jangka pendek dan akrual diskresioner jangka panjang. Akrual diskresioner jangka pendek memiliki waktu yang relatif pendek misalnya satu tahun atau kurang dari satu tahun (satu periode akuntansi) sedangkan akrual diskresioner jangka panjang memiliki jangka waktu lebih dari satu tahun periode akuntansi.

\section{Konservatisme Akuntansi}

Konservatisme dapat didefinisikan sebagai tendensi yang dimiliki oleh seorang akuntan yang mensyaratkan tingkat verifikasi yang lebih tinggi untuk mengakui laba dibandingkan dengan mengakui rugi, Prinsip konservatisme juga seringkali dikaitkan dengan kualitas laba dan menjadi nilai perusahaan, konservatisme akuntansi akan mempengaruhi baik kualitas laba yang dilaporkan dalam laporan keuangan maupun kualitas akun finansial (seperti aset dan hutang) yang dilaporkan dalam neraca perusahaan.

Gul et al (2002), konservatisme adalah reaksi yang hati-hati dalam menghadapi ketidakpastian, dimana dalam menghadapi ketidakpastian perusahaan mempertimbangkan risiko yang inhern dalam lingkungan bisnis, hal ini dipertegas oleh Handojo (2012) yang meyatakan bahawa konservatisme menyebabkan data yang dilaporkan tidak bisa dinterpretasikan secara tepat, karena yang dilaporkan dalam laporan keuangan mengenai angka-angka yang rentang untuk hal-hal yang menguntungkan namun angka yang relatif tinggi untuk hal-hal yang merugikan.

Watts (2003), mengungkapkan ada tiga tujuan konservatisme antara lain adalah (1) Membatasi manajer dalam berperilaku oportunistik. Manajer yang mempunyai tanggungjawab terhadap laporan keuangan kepada investor dalam hal pengambilan keputusan, membuat manajemen cenderung mempengaruhi angka-angka dalam laporan keuangan untuk kepentingan manajemen. Dalam hal ini konservatisme bisa membatasi perilaku manajemen untuk bertindak oportunistik, (2) Meningkatkan nilai perusahaan. Dengan membatasi adanya perilaku oportunistik dari manajemen maka nilai perusahaan dapat meningkat, (c) Mengurangi potensi tuntutan hukum; Peningkatan laba yang terlalu tinggi mendorong tingginya tuntutan hukum yang harus dilaksanakan, dengan adanya hal tersebut maka mendorong manajemen bertindak konservatif. (3) Mentaati peraturan, Peraturan yang dibuat oleh penyusun standar, memberikan perusahaan untuk melakukan penetapan metoda peniliaian persediaan pada harga yang fluktuatif.

Penyataan Standar Akuntansi Keuangan (PSAK) masih memberikan peluang dalam penerapan prinsip konservatisma; a) PSAK No.13 mengenai akuntansi untuk investasi, menyatakan bahwa biaya dapat ditentukan berdasarkan FIFO, rata-rata tertimbang, atau LIFO. Nilai pasar dapat ditentukan portofolio agregat, dalam total atau menurut urutan kategori investasi, atau investasi individual, secara konsisten, b) PSAK No.14 memberikan kebijakan kepada manajemen, bahwa manajemen perusahaan dapat mencatat dan menghitung biaya persediaan dengan menggunakan salah satu metode dengan menggunakan rumus FIFO, LIFO dan rata- rata tertimbang. c) PSAK No.16 mengijinkan manajemen untuk mengestimasi masa manfaat suatu aset tetap berdasarkan pertimbangan yang berasal dari pengalaman perusahaan ketika menggunakan aktiva serupa. Aset tetap dan penyusutan yang mengatur estimasi masa manfaat suatu aktiva tetap. 
Menurut Manik (2017), ruang linkup perlakuan prinsip konservatisme akuntansi antara lain: 1) Kompensasi kerugian menyebabkan pengakuan piutang pajak tangguhan. Aset pajak tangguhan diakui untuk akumulasi rugi pajak belum dikompensasi apabila besar kemungkinan laba kena pajak masa depan akan memadai untuk dimanfaatkan dengan rugi pajak belum dikompensasi. Kriteria probabilitas (kemungkinan) merupakan kriteria kualitatif yang bersifat subjektif dimana dengan adanya kriteria subjective judgement ini terbuka peluang untuk menerapkan konservatisme. 2) Kapitalisasi biaya pengembangan. Salah satu syarat aset tak berwujud yang timbul seperti biaya pengembangan (atau dari tahap pengembangan pada proyek internal) diakui apabila memenuhi bagaimana aset tak berwujud tersebut akan menghasilkan kemungkinan besar manfaat ekonomi masa depan.

Implementasi atas asas konservatisme yaitu jika terdapat sesuatu yang dapat meningkatkan aktiva, tetapi belum terealisasi, maka kejadian itu belum boleh diakui. Tetapi jika terdapat sesuatu yang mengakibatkan penurunan aktiva, walaupun belum terealisasi, maka kejadian itu harus sudah diakui. Dalam sebuah perusahaan memperbarui estimasi mengenai arus kas masa depan dari biaya pengembangan yang dikapitalisasinya, mungkin ada efek sementara konservatisme yang mengarah pada penciptaan cadangan tersembunyi yang kemudian dapat dibalik kembali (Reversed). Penyajian informasi keuangan dihadapkan pada prinsip kehati-hatian, yakni terhadap pencatatan pendapatan dan biaya, maupun pencatatan terhadap aktiva.

\section{Kinerja Perusahaan}

Mengukur kinerja perusahaan melalui informasi dalam laporan keuangan, dalam laporan keuangan menyajikan aspek-aspek finansial perusahaan pada suatu periode akuntansi. Menurut Sulistyanto (2008), ukuran kinerja untuk membantu menerapkan strategi dan pengendalian manajemen sebagai faktor keberhasilan penting (critical success factors) jangka pendek dan jangka panjang. Ukuran kinerja merupakan suatu mekanisme memperbaiki perusahaan mengimplementasikan starteginya dengan berhasil tanpa melakukan manipulasi data keuangan perusahaan.

Antony (2005), menjelaskan bahawa peningkatan kinerja jangka pendek dan jangka panjang, tidak cukup dengan ukuran-ukuran keungan faktanya dapat menjadi fungsional dengan alasan sebagai berikut; 1) Mendorong tindakan jangka pendek yang tidak sesuai dengan kepentingan jangka panjang perusahaan, 2) Manager tidak mengambil tindakan jangka panjang, guna memperoleh jangka pendek, 3) Menggunakan laba jangka pendek sebagai satu-satunya tujuan dapat mendistorsi komunikasi antara manager dengan manajemen puncak (CEO), 4) Pengendalian keuangan yang ketat dapat memotivasi manajer untuk memanipulasi data laporan keuangan.

\section{Nilai Perusahaan}

Rika (2010), mengungkapkan bahawa nilai perusahaan didefinisikan sebagai nilai pasar. Nilai perusahaan dapat memberikan kemakmuran pemegang saham secara maksimum apabila harga saham perusahaan meningkat. Semakin tinggi harga saham, maka makin tinggi kemakmuran pemegang saham. Untuk mencapai nilai perusahaan umumnya para pemodal menyerahkan pengelolaannya kepada para profesional. Para profesional diposisikan sebagai manajer ataupun komisaris. 
Salah satu alternatif pengukuran nilai perusahaan dengan teori yang digunakan dalam menilai perusahaan yang dikembangkan oleh James Tobin's Q (1967). Tobin's Q merupakan harga pengganti dari biaya yang dibutuhkan guna memperoleh aset yang sama persis dengan aset yang dimiliki perusahaan, mengungkapkan bahwa rasio ini hampir sama dengan market-tobook-value ratio, sehingga analisis teori bahawa niilai pasar perusahaan merupakan harga saham perusahaan yang terbentuk dari transakasi antara penjual dan pembeli, karena harga pasar saham dianggap sebagai gambaran dari nilai aset perusahaan.

Beberapa pnelitiang mengukur nilai perusahaan publik ditentukan oleh pasar saham. Nilai perusahaan yang sahamnya tidak diperdagangkan kepada publik juga sangat dipengaruhi oleh pasar yang sama, shingga Nilai perusahaan pada penelitian ini diukur dengan menggunakan rasio price book value (Mardayati,. at. Ell, 2012). Nilai perusahaan didefinisikan sebagai nilai pasar. Karena nilai perusahaan dapat memberikan kemakmuran pemegang saham secara maksimum apabila harga saham perusahaan meningkat. Semakin tinggi harga saham, maka makin tinggi kemakmuran pemegang saham. Untuk mencapai nilai perusahaan umumnya para pemodal menyerahkan pengelolaannya kepada para profesional. Para profesional diposisikan sebagai manajer ataupun komisaris.

Dyah (2012), menjelaskan bahwa peningkatan nilai perusahaan yang tinggi merupakan tujuan jangka panjang yang seharusnya dicapai perusahaan yang tercermin dari harga pasar sahamnya karena penilaian investor terhadap perusahaan dapat diamati melalui pergerakan harga saham perusahaan yang ditransaksikan di bursa untuk perusahaan yang sudah go public. Dalam proses memaksimalkan nilai perusahaan akan muncul konflik kepentingan antara manajer dan pemegang saham (pemilik perusahaan) yang sering disebut agency problem.

\section{Pengembangan Hipotesis}

\section{Pengaruh Manajemen Laba Terhadap Nilai Perusahaan dengan Kinerja Perusahaan sebagai variabel pemoderasi}

Menurut Scott (2003), motivasi manajemen melakukan tindakan pengaturan laba atau manajemen laba adalah 1) Rencana Bonus (bonus scheme), 2) Kontrak utang jangka panjang (Debt Covenant), 3) Motivasi Politis (political motivation), 4) Motivasi Perpajakan (taxation motivation), 5) Pergantian Direksi Beragam motivasi timbul disekitar waktu pergantian direksi, 6) Penawaran Perdana (initial public offering)

Ketika perusahaan dinyatakan telah go public, informasi keuangan yang ada didalam prospektus merupakan sumber informasi enting. Informasi ini dapat digunakan sebagai sinyal kepada calon investor tentang nilai perusahaan. untuk mempengaruhi keputusan calon investor, maka manajer berusaha menaikkan laba yang dilaporkan. Selain itu, motivasi pasar modal juga mempengaruhi dalam tindakan manajemen laba. Penggunaan informasi secara luas oleh investor dan analisi keuangan untuk melindungi nilai sekuritasnya, dapat menciptakan dorongan manajer untuk memanipulasi laba dalam usahanya untuk mempengaruhi kinerja sekuritas jangka pendek. Berdasarkan teori diatas, maka hipotesis yang dikembangkan dari uraian di atas adalah :

H1 : Manajemen laba berpengaruh terhadap nilai perusahaan

H4 : Manajemen laba berpengaruh terhadap nilai perusahaan dengan Kinerja Perusahaan sebagai variabel pemoderasi 


\section{Pengaruh Konservatisme terhadap nilai perusahaan dengan Kinerja Perusahaan sebagai variabel pemoderasi}

Konservatisme akuntansi terjadi karena standar akuntansi yang berlaku di Indonesia memperbolehkan untuk memilih metode akuntansi. Handojo (2012), menyatakan bahwa konservatisme menyebabkan data yang dilaporkan tidak bisa dinterpretasikan secara tepat, karena yang dilaporkan dalam laporan keuangan mengenai angka-angka yang rentang untuk halhal yang menguntungkan namun angka yang relatif tinggi untuk hal-hal yang merugikan. Prinsip konservatisme dalam pelaporan keuangan yang dimaksudkan untuk mengakui dan mengukur aktiva dan laba dilakukan dengan penuh kehati-hatian oleh karena aktivitas ekonomi dan bisnis yang dilingkupi ketidakpastian. Implikasi dari penerapan prinsip ini adalah pilihan metode akuntansi ditujukan pada metode yang melaporkan laba dan aktiva lebih rendah atau utang lebih tinggi. Berdasarkan teori diatas, maka hipotesis yang dikembangkan dari uraian di atas adalah :

\section{$\mathrm{H} 2$ : Konservatisme berpengaruh terhadap nilai perusahaan \\ H5 : Konservatisme terhadap berpengaruh terhadap nilai perusahaan dengan Kinerja Perusahaan sebagai variabel pemoderasi}

\section{Pengaruh Kinerja Perusahaan terhadap Nilai Perusahaan}

Pada dasarnya bahwa pengukuran kinerja perusahaan, selain dilihat dari perspektif kinerja financial dan non financial, juga dapat dilihat dari perspektif kepentingan atau tujuan analisisnya. Pengguna laporan keungan dapat membedakan perspektif eksternal dan internal. Pengukuran kinerja dari perspektif eksternal, terutama dilakukan oleh investor ekuitas dan kreditor. Dari perspektif ini, tujuan analisis kinerja keuangan perusahaan terutama dimaksudkan untuk valuation, yaitu menilai prospek dan risiko perusahaan yang tercermin dari present value harga saham dan nilai perusahaan secara keseluruhan, sehingga dengan mengetahui present value harga saham, maka para investor dan kreditor dapat mengambil keputusan atas investasi pada perusahaan tersebut. Keputusan ini dapat berupa: hold, buy, atau sell atas kepemilikan saham pada perusahaan tersebut. Berdasarkan teori diatas, maka hipotesis yang dikembangkan dari uraian di atas adalah :

H3 : Kinerja perusahaan berpengaruh terhadap nilai perusahaan

\section{METODOLOGI PENELITIAN}

\section{Jenis dan Sumber Data Penelitian}

Jenis data yang digunakan dalam penelitian ini adalah data sekunder, yaitu data-data yang disediakan oleh pihak lain dan tidak berasal dari sumber langsung. Data yang diperoleh berupa laporan keuangan perusahaan manufaktur yang dipublikasikan oleh Bursa Efek Indonesia (BEI) tahun 2016 - 2017. Populasi yang digunakan dalam penelitian ini adalah semua perusahaan manufaktur yang terdaftar di Bursa Efek Jakarta (BEJ). Pengambilan sampel dilakukan dengan metode purposive sampling. Jumlah populasi 168 yang memenuhi kriteria sebanyak 40 perusahaan, maka data penelitian $40 \times 2$ tahun yaitu 80 data

\section{Metode Analisis dan Hipotesisi Penelitian}

Pengujuan dengan aplikasi SPSS untuk menguji statistik deskriptif, Kemudian pengujian asumsi klasik sebagai salah satu syarat untuk bisa menggunakan persamaan regresi berganda adalah terpenuhinya uji asumsi klasik. Empat uji asumsi klasik dalam penelitian ini meliputi normalitas, asumsi heteroskedastisitas, autokorelasi dan multikolinearitas. Penjelasan masing- 
masing pengujian asumsi klasik akan diuraikan seperti di bawah ini. Lanjutan pengujian untuk metode analisis yang digunakan untuk menguji pengaruh variabel bebas terhadap terikat dengan Uji T, Uji F dan Uji Determinasi

\section{Operasional Pengukuran Variabel}

\section{Manajemen Laba}

Dalam penelitian ini, manajemen laba yang dimaksud adalah tindakan manajemen yang dilakukan dengan tujuan untuk meningkatkan kemakmuran individu atau untuk meningkatkan nilai perusahaan. Manajemen laba (DACC) dapat diukur melalui discretionary accruals yang dihitung dengan cara menselisihkan total accruals (TACC) dan nondiscretionary accruals (NDACC). Dalam menghitung DACC, digunakan Modified Jones Model. Semakin kecil discretionary accruals semakin tinggi kualitas laba dan sebaliknya. Laba akuntansi akan dicatat dan diuraikan dalam arus kas operasi dan accruals. Acccruals terdiri dari discretionary dan non discretionary accruals. Discretionary accruals merupakan penyesuaian arus kas oleh manajer dari serangkaian kesempatan prosedur akuntansi yang disusun oleh manajemen.

Pengukuran manajemen laba menggunakan Modified Jones Model (1991), dapat mendeteksi manajemen laba lebih baik dibandingkan dengan model-model lainnya sejalan dengan hasil penelitian Dechow dkk. (1995), Rahmawati, dkk. (2006), Triatmoko (2007), Sulistiyanto (2008), Manik, Tumpal (2010) disetimasikan dengan persamaan berikut :

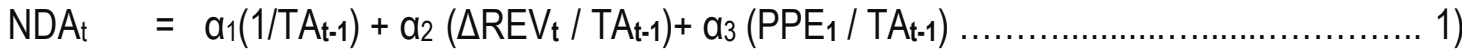

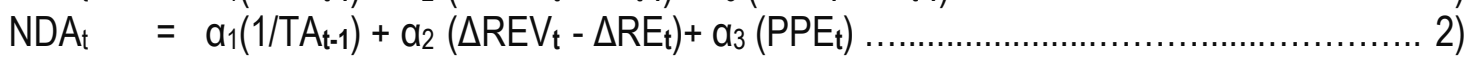

$$
\begin{aligned}
& \mathrm{DA}_{\mathrm{it}}=\mathrm{TA} \text { it }-\mathrm{NDA}_{\mathrm{it}} \text {...... }
\end{aligned}
$$

Keterangan :

$\triangle R E V_{t}=$ revenue pada tahun $t$ dikurangi revenue pada tahun $\mathrm{t}-1$ dibagi total aktiva tahun $\mathrm{t}-1$.

$\mathrm{PPE}_{\mathrm{t}} \quad=$ gross property plan and equipment pada tahun $\mathrm{t}$ dibagi total aktiva tahun $\mathrm{t}-1$

$\mathrm{A}_{\mathrm{t}-1}=$ total aktiva tahun $\mathrm{t}-1$

$\mathrm{a} 1, \mathrm{a} 2, \mathrm{a} 3=$ Firm-spesific parameters

$\Delta \mathrm{REC}_{\mathrm{t}}=$ net receivable (piutang bersih) pada tahun $\mathrm{t}$ dikurangi piutang bersih pada tahun $\mathrm{t}-1$ dibagi total aktiva tahun $\mathrm{t}-1$.

TAit = total akrual (untuk yang model akrual khusus, total akrual dihitung berdasarkan total saldo penyisihan penghapusan aktiva produktif (PPAP)

DAit $=$ akrual kelolaan

NDAit $=$ akrual non kelolaan

\section{Konservatisme Akuntansi}

Ukuran konservatisme yang digunakan dalam penelitian ini adalah ukuran akrual yang merupakan variabel terikat dalam model penelitian. Ukuran konservatisme dengan menggunakan akrual, sesuai dengan yang digunakan oleh Givoly dan Hayn (2002) dalam Ahmed dan Duellman (2007), Manik (2017). Rumus untuk mengukur konservatisme yaitu:

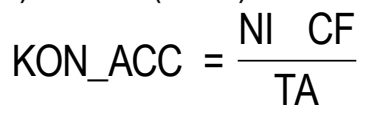

\section{Dimana:}

KON_ACC: Tingkat konservatisme akuntansi

$\mathrm{NI} \quad$ : Laba sebelum extraordinary items

Hal. 8 


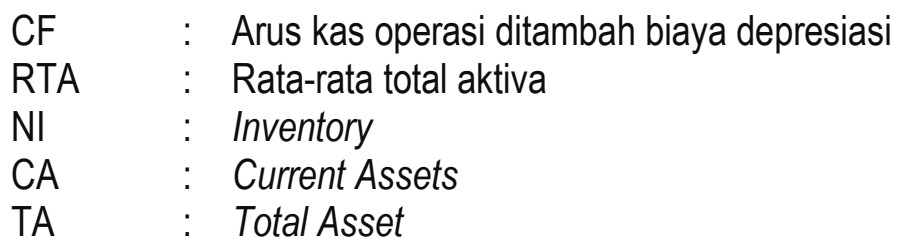

\section{Kinerja Perusahaan}

Pengukuran kinerja perusahaan berdasarkan peningkatan laba dan pertumbuhan aset dalam setiap periode akuntansi, termasuk kemampuan perusahaan membayar hutang jangka pendek dan jangka panjang tanpa hurus mengurangi belanja lainnya. Dalam penelitian ini bahawa kinerja berhubungan dengan penilaian prestasi suatu perusahaan dapat dilihat dari kemampuan perusahaan itu untuk menghasilkan laba. Laba perusahaan selain merupakan indikator kemampuan perusahaan memenuhi kewajiban kepada para penyandang dananya juga merupakan alat untuk penciptaan nilai perusahaan yang menunjukkan prospek ekspektasi perusahaan di masa yang akan datang.

Kinerja perusahaan menggunakan kinerja keuangan yang diproksikan dengan Return On Asset (ROA). ROA adalah salah satu bentuk dari rasio profitabilitas yang dimaksudkan untuk mengukur kemampuan perusahaan dalam mengoptimalkan keseluruhan dana yang ditanamkan untuk operasional perusahaan dengan tujuan menghasilkan laba yang maksimal. ROA dihitung dengan formula sebagai berikut:

$$
\mathrm{ROA}=\frac{\text { Laba Bersih }}{\text { Jumlah Aktiva }} \times 100 \%
$$

\section{Nilai Perusahaan}

Variabel dependen atau variabel terikat merupakan variabel yang dipengaruhi atau menjadi akibat, karena adanya variabel bebas (Sugiyono, 2008:59). Variabel dependen pada penelitian ini adalah Nilai Perusahaan. Nilai perusahaan merupakan persepsi investor terhadap tingkat keberhasilan perusahaan yang sering dikaitkan dengan harga saham (Sujoko dan Soebiantoro (2007) dalam Hardiyanti (2012). Nilai perusahaan dalam penelitian ini diukur dengan menggunakan rasio Tobin's $Q$. Rasio Tobin's $Q$ dihitung dengan menggunakan rumus sebagai berikut :

$$
Q=\frac{(M V S+T L+l) C A}{T A}
$$

Dimana :

$Q \quad=$ Nilai Perusahaan

MVS = Market Value of all outstanding shares (Stock Price * Outstanding Shares)

$\mathrm{TL}=$ Total Liabilities 


\section{HASIL DAN PEMBAHASAN}

\section{Pengujian Secara Parsial}

Hasil pengujian penelitian menunjukkan bahwa semua varabel bebas berpengaruh signifikan terhadap nilai variabel terikat

Tabel1. Pengujuan Secara Parsial

Pengarauh Manajemen Laba Dan Konservatisme Akuntansi

Terhadap Nilai Perusahaan

\begin{tabular}{|c|c|c|c|c|}
\hline \multicolumn{4}{|l|}{ Keterangan } & Nilai \\
\hline \multicolumn{4}{|l|}{ R Square } & 0.781 \\
\hline \multicolumn{4}{|l|}{ Adjusted R Square } & 0.778 \\
\hline \multicolumn{4}{|l|}{ F hitung } & 209.614 \\
\hline \multicolumn{4}{|l|}{ Probabilitas } & 0.000 \\
\hline Keterangan & $\begin{array}{c}\text { Unstandardized } \\
\text { Coefficients }\end{array}$ & $\begin{array}{c}\text { Standardized } \\
\text { Coefficients }\end{array}$ & Uji-T & $\begin{array}{l}\text { Probabilitas } \\
\text { (Sig. a } 0,05)\end{array}$ \\
\hline (Constant) & 8.918 & & 14.449 & 0.000 \\
\hline Manajemen Laba (X1) & -0.176 & -0.317 & -8.545 & 0.000 \\
\hline Konservatisme (X2) & 0.213 & 0.426 & 10.235 & 0.000 \\
\hline Kinerja Perusahaan (Z) & 0.227 & 0.443 & 11.074 & 0.000 \\
\hline
\end{tabular}

a. Dependent Variable: Nilai Perusahaan

b. Predictors: (Constant), Manajemen Laba, Konservatisme, Kinerja Perusahaan

Output SPSS V.24, (2018)

Tabel 1 diatas menunjukkan bahwa semua variabel independen berpengaruah signifikan terhadap variabel dependen, hasil pengujian diformulasikan dalam regresi berganda dari pengujian tabel 1 secara parsial sebagai berikut :

\section{Nilai Perusahaan $=8.918 \alpha+0.176$ Manajemen Laba +0.213 Konservatisme +0.227 Kinerja Perusahaan}

Berdasarkan tabel 1 diatas, menunjukkan bahwa interpretasi hasil penelitian sesaui dengan tujuan penelitian ini adalah :

H1 Manajemen laba memberikan koefisien parameter 0.176 dengan tingkat signifikansi (a) yakni $0,000<0,05$, hipotesis menunjukkan bahwa manajemen laba berpengaruh signifikan terhadap nilai perusahaan sebesar $-17,6 \%$. Artinya jika praktik manajemen laba meningkat maka nilai perusahaan akan mengalami penurunan. Nilai perusahaan dilihat dari pertumbuhan kas operasional dan peningktan pendapatan yang tercatat dalam informasi laporan keuangan.

$\mathrm{H} 2$ Konservatisme memberikan koefisien parameter 0.213 dengan tingkat signifikansi (a) yakni $0,000<0,05$, artinya penerapan konservatisme akuntansi berpengaruh signifikan terhadap nilai perusahaan sebesar $21,3 \%$.

H3 Kinerja Perusahaan memberikan koefisien parameter 0.227 dengan tingkat signifikansi (a) yakni $0,000<0,05$, artinya kinerja perusahaan berpengaruh signifikan terhadap nilai perusahaan sebesar $22,7 \%$. Jika kinerja perusahaan semakin meningkat maka nilai perusahaan semakin bagus. 


\section{Pengujian Moderasi Pertama}

Hasil pengujian variabel moderasi (kinerja perusahaan) terhadap nilai perusahaan memiliki pengaruh yang signifikan di tunjukkan dalam tabel 2 dibawah ini

Tabel 2. Pengujian Pengaruh Manajemen Laba dan Variabel Moderasi (Kinerja Perusahaan) Terhadap Nilai Perusahaan

\begin{tabular}{|c|c|c|c|c|}
\hline \multicolumn{4}{|l|}{ Keterangan } & Nilai \\
\hline \multicolumn{4}{|l|}{ R Square } & 0.629 \\
\hline \multicolumn{4}{|l|}{ Adjusted R Square } & 0.625 \\
\hline \multicolumn{4}{|l|}{ F hitung } & 150.019 \\
\hline \multicolumn{4}{|l|}{ Probabilitas } & 0.000 \\
\hline Keterangan & $\begin{array}{c}\text { Unstandardized } \\
\text { Coefficients }\end{array}$ & $\begin{array}{c}\text { Standardized } \\
\text { Coefficients }\end{array}$ & Uji-T & $\begin{array}{l}\text { Probabilitas } \\
\text { (Sig. a } 0,05)\end{array}$ \\
\hline (Constant) & 12.142 & & 17.177 & 0.000 \\
\hline Manajemen Laba (X1) & 0.175 & 0.315 & 6.537 & 0.000 \\
\hline Kinerja Perusahaan $(\mathrm{Z})$ & 0.317 & 0.636 & 13.188 & 0.000 \\
\hline
\end{tabular}

a. Dependent Variable: Nilai Perusahaan

b. Predictors: (Constant), Manajemen Laba (X1), Nilai Perusahaan (Z)

Output SPSS V.24, (2018)

Tabel 2 diatas melihat pengaruh kinerja perusahaan sebagai variabel pemoderasi terhadap nilai perusahaan, Hasil pengujian menunjukkan bahwa kinerja perusahaan memiliki pengaruh yang signifikan $0,000<0,05$, terhadap nilai perusahaan, pengaruhnya sebesar $31,17 \%$.

Tabel 3. Pengujian Pengaruh Manajemen Laba Terhadap Nilai Perusahaan yang Dimoderasi Oleh Kinerja Perusahaan

\begin{tabular}{|c|c|c|c|c|}
\hline \multicolumn{4}{|l|}{ Keterangan } & Nilai \\
\hline \multicolumn{4}{|l|}{ R Square } & 0.770 \\
\hline \multicolumn{4}{|l|}{ Adjusted R Square } & 0.766 \\
\hline \multicolumn{4}{|l|}{ F hitung } & 196.528 \\
\hline \multicolumn{4}{|l|}{ Probabilitas } & 0,000 \\
\hline Keterangan & $\begin{array}{l}\text { Unstandardized } \\
\text { Coefficients }\end{array}$ & $\begin{array}{c}\text { Standardized } \\
\text { Coefficients }\end{array}$ & Uji-T & $\begin{array}{l}\text { Probabilitas } \\
\text { (Sig. a 0,05) }\end{array}$ \\
\hline (Constant) & 14.479 & & 24.069 & 0.000 \\
\hline Manajemen Laba (X1) & -0.056 & -.100 & -1.817 & 0.041 \\
\hline Kinerja Perusahaan (Z) & 0.217 & 0.435 & 10.199 & 0.000 \\
\hline Interaksi Moderasi 1 & 0.009 & 0.637 & 10.395 & 0.000 \\
\hline
\end{tabular}
a. Dependent Variable: Nilai Perusahaan
b. Predictors: (Constant), Manajemen Laba, Kinerja Perusahaan, Interaksi Moderasi 1
Output SPSS V.24, (2018) 
Berdasarkan tabel 3 diatas menunjukkan bahwa dari ketiga variable independen semua berpengaruh secara signifikan terhadap nilai perusahaan, antara lain :

H4 Variabel moderasi (Manajemen Laba $x$ Kinerja Perusahaan) memiliki koefisien parameter 0.009 ternyata berpengaruh signifikan karena nilai Sig. $0,00>0,05$. Pengujian output pertama dalam tabel 2 sebelumnya menunjukkan bahwa kinerja perusahaan memiliki pengaruh yang signifikan $0,000<0,05$, terhadap nilai perusahaan, pengaruhnya sebesar $31,17 \%$. Pengujian output pertama (tabel 2 ) dan pengujian dalam tabel 3 sebagai iteraksi variabel moderasi sama-sama memiliki pengaruh yang signifikan sehingga dapat disimpulkan bahwa variabel kinerja perusahaan (pemoderasi) disebut iteraksi variabel sebagai Quasi Moderator, artinya variabel pemoderasi kinerja perusahaan memperkuat atau meningkatkan pengaruh manajemen laba terhadap nilai perusahaan sebesar $9 \%$

\section{Pengujian Moderasi Kedua}

Hasil pengujian variabel moderasi kedua variabel konservatisme dan kinerja perusahaan (varibel pemoderasi) terhadap nilai perusahaan memiliki pengaruh yang signifikan di tunjukkan dalam tabel dibawah ini :

Tabel 4. Pengujian Pengaruh Konservatisme dan Variabel Moderasi (Kinerja Perusahaan) Terhadap Nilai Perusahaan

\begin{tabular}{|c|c|c|c|c|}
\hline \multicolumn{4}{|l|}{ Keterangan } & Nilai \\
\hline \multicolumn{4}{|l|}{ R Square } & .781 \\
\hline \multicolumn{4}{|l|}{ Adjusted R Square } & .778 \\
\hline \multicolumn{4}{|l|}{ F hitung } & 209.614 \\
\hline \multicolumn{4}{|l|}{ Probabilitas } & 0.000 \\
\hline Keterangan & $\begin{array}{c}\text { Unstandardized } \\
\text { Coefficients }\end{array}$ & $\begin{array}{c}\text { Standardized } \\
\text { Coefficients }\end{array}$ & Uji-T & $\begin{array}{l}\text { Probabilitas } \\
\text { (Sig. a } 0,05)\end{array}$ \\
\hline (Constant) & 8.918 & & 14.449 & 0.000 \\
\hline Konservatisme (X2) & 0.176 & 0.317 & 8.545 & 0.000 \\
\hline Kinerja Perusahaan (Z) & 0.227 & 0.443 & 11.074 & 0.000 \\
\hline
\end{tabular}

a. Dependent Variable: Nilai Perusahaan

b. Predictors: (Constant), Konservatisme (X2), Kinerja Perusahaan (Z)

Output SPSS V.24, (2018)

Tabel 4 diatas melihat pengaruh kinerja perusahaan sebagai variabel pemoderasi terhadap nilai perusahaan, Hasil pengujian menunjukkan bahwa nilai perusahaan memiliki pengaruh yang signifikan $0,000<0,05$, terhadap kinerja perusahaan, pengaruhnya sebesar $22,7 \%$.

Tabel 5. Pengujian Pengaruh Konservatisme Terhadap Nilai Perusahaan yang Dimoderasi Oleh Kinerja Perusahaan

\begin{tabular}{|lr|}
\hline Keterangan & Nilai \\
\hline R Square & 0.858 \\
\hline Adjusted R Square & 0.855 \\
\hline F hitung & 353.403 \\
\hline Probabilitas & 0,000 \\
\hline
\end{tabular}




\begin{tabular}{|l|r|r|r|c|}
\hline Keterangan & $\begin{array}{c}\text { Unstandardized } \\
\text { Coefficients }\end{array}$ & $\begin{array}{c}\text { Standardized } \\
\text { Coefficients }\end{array}$ & Uji-T & $\begin{array}{c}\text { Probabilitas } \\
\text { (Sig. a 0,05) }\end{array}$ \\
\hline (Constant) & 11.613 & & 26.380 & 0.000 \\
\hline Konservatisme (X2) & 0.134 & 0.242 & 8.002 & 0.000 \\
\hline Kinerja Perusahaan (Z) & 0.143 & 0.287 & 7.890 & 0.000 \\
\hline Interaksi Moderasi 2 & 0.009 & 0.609 & 16.813 & 0.000 \\
\hline
\end{tabular}

a. Dependent Variable: Nilai Perusahaan

b. Predictors: (Constant), Konservatisme (X2), Kinerja Perusahaan (Z), Interaksi Moderasi 2

Output SPSS V.24, (2018)

Berdasarkan tabel 5 diatas menunjukkan bahwa dari ketiga variabel yang dimasukkan berpengaruh secara signifikan terhadap nilai perusahaan, antara lain :

H5 Variabel moderasi (Konservatisme $\mathrm{x}$ Kinerja Perusahaan) memiliki koefisien parameter 0.009 ternyata berpengaruh signifikan karena nilai Sig. 0,00 >0,05. Pengujian output pertama dalam tabel 4 sebelumnya menunjukkan bahwa nilai perusahaan memiliki pengaruh yang signifikan $0,000<0,05$, terhadap kinerja perusahaan, pengaruhnya sebesar $22,7 \%$. Pengujian output pertama (tabel 4 ) dan pengujian dalam tabel 5 sebagai iteraksi variabel moderasi sama-sama memiliki pengaruh yang signifikan, sehingga dapat disimpulkan bahwa variabel kinerja perusahaan sebagai (pemoderasi) disebut iteraksi variabel sebagai Quasi Moderator, artinya variabel pemoderasi kinerja perusahaan memperkuat atau meningkatkan pengaruh konservatisme terhadap nilai perusahaan sebesar $9 \%$

\section{KESIMPULAN DAN REKOMENDASI KEBIJAKAN}

\section{Kesimpulan}

Berdasarkan hasil penelitian dengan interpretasi, maka peneliti memberikan kesimpulan, antara lain :

1. Hasil penelitian menunjukkan bahwa Manajemen laba memberikan berpengaruh signifikan terhadap nilai perusahaan sebesar $-17,6 \%$. Artinya jika praktik manajemen laba meningkat maka nilai perusahaan akan mengalami penurunan. Nilai perusahaan dilihat dari pertumbuhan kas operasional dan peningktan pendapatan yang tercatat dalam informasi laporan keuangan.

2. Konservatisme berpengaruh signifikan terhadap nilai perusahaan sebesar $21,3 \%$.

3. Kinerja Perusahaan berpengaruh signifikan terhadap nilai perusahaan sebesar $22,7 \%$.

4. Variabel moderasi (Manajemen Laba $x$ Kinerja Perusahaan) memiliki pengaruh signifikan terhadap nilai perusahaan, pengaruhnya sebesar $31,17 \%$. Hasil dapat disimpulkan bahwa variabel kinerja perusahaan (pemoderasi) disebut iteraksi variabel sebagai Quasi Moderator, artinya variabel pemoderasi kinerja perusahaan memperkuat atau meningkatkan pengaruh manajemen laba terhadap nilai perusahaan sebesar $9 \%$

5. Variabel moderasi (Konservatisme $\mathrm{x}$ Kinerja Perusahaan) berpengaruh signifikan terhadap nilai perusahaan sebesar 22,7\%. Pengujian disimpulkan bahwa variabel kinerja perusahaan sebagai (pemoderasi) disebut iteraksi variabel sebagai Quasi Moderator, artinya variabel pemoderasi kinerja perusahaan memperkuat atau meningkatkan pengaruh konservatisme terhadap nilai perusahaan sebesar $9 \%$ 


\section{Rekomendasi Kebijakan}

Hasil penelitian ini menunjukkan bahwa manajemen laba dan konservatisme akuntansi berpengaruh terhadap terhadap nilai perusahaan dengan kinerja perusahaan sebagai variabel pemoderasi. Kinerja perusahaan dapat memperkuat nilai perusahaan apabila dalam perusahaan menerapkan praktir manajemen laba, kemudian kinerja perusahaan mampu memperkuat hubungan antara konservatisme akuntansi dengan nilai perusahaan.

Penelitian ini perlu dilakukan penelitian lanjut untuk membuktikan secara ilmiah tentang teori dan interpretasi dari data riset bidang ilmu akuntansi keuangan dan manajemen khusunya materi bidang manajemen laba, konservatisme akuntansi, nilai perusahaan dankinerja perusahaan, baik penelitian dengan pemoderasi maupun intervenning.

\section{DAFTAR PUSTAKA}

Anthony Robert. N dan Givindarajan Vijay (2005), Manajemen Control System, Mc Grawi Hill, Terjemahan Sistem Pengendalian Manajemen 2, Salemba 4, Jakarta.

Dyah, Reny Retno M, Denies Priantinah (2012), Pengaruh Good Corporate Governance Dan Pengungkapan Corporate Social Responsibility Terhadap Nilai Perusahaan (Studi Empiris Pada Perusahaan Yang Terdaftar Di Bursa Efek Indonesia Periode 2007-2010) Jurnal Nominal, Volume I, Nomor I, Tahun 2012, Fakultas Ekonomi Universitas Negeri Yogyakarta

Gul, Ferdinand A, dan Bin Srinindhi et al. (2002), The Asian Financial Crisis, Accounting Conservatism and Audit Fees: Evidence From Hong Kong. Working Paper.

Handojo, Irwanto. (2012). Sekelumit Konservatisme Akuntansi. Media. 1-12

Manik Tumpal (2010), Pengaruh Praktek Earning Management Melalui Accrual Dan Manipulasi Operasional Terhadap Kinerja Jangka Panjang Perusahaan Saat Penawaran Saham Tambahan (Studi Empiris Periode Tahun 2005-2009), Jurnal Ekonomi Maritim Universitas Maritim Raja Ali Haji, Vol.1, N0,1 Desember 2010.

Manik Tumpal (2017), Praktik Konservatisme Akuntansi Melalui Mekanisme Corporate Governance Terhadap Kualitas Laba, Jurnal IImiah Akuntnasu dan Finansial Indonesia Vol.1, No.1 Oktorber 2017.

Mardiyati, Umi; Gatot Nazir Ahmad; Ria Putri (2012), Pengaruh Kebijakan Dividen, Kebijakan Hutang Dan Profitabilitas Terhadap Nilai Perusahaan Manufaktur Yang Terdaftar Di Bursa Efek Indonesia (Bei) Periode 2005-2010. Jurnal Riset Manajemen Sains Indonesia (Jrmsi) |Vol. 3, No. 1, 2012.

Rika, Susanti. (2010). Analisis Faktor-Faktor Yang Berpengaruh Terhadap Nilai Perusahaan. Skripsi. Manajemen Keuangan. FE. Universitas Diponegoro.

Roychowdhury, S. (2006). "Earnings Management through Real Activities Manipulation." Journal of Accounting and Economics. 42: 335-370.

Scott; Willian. Robert (2003), "Financial Accounting Teory Thirt Edition", University of Waterloo. Torornto, Ontorio

Sulistiyanto, Sri. H (2008), "Manajemen Laba Teori dan Model Empiris", PT Grasindo, Anggota IKAPI. Jakarta.

Watts, R.L. (2003), Conservatism in accounting part l: explanations and implications. Journal of Accounting and Economics. 207-221. 